\title{
A REVIEW OF DISCLOSURE TRANSLATION SHOWING GENDER DISCRIMINATION AND SOCIAL CLASS DISCRIMINATION IN NOVEL GIRL FROM THE COAST
}

\author{
Nunun Tri Widarwati, Ratih Wijayava, Giyatmi \\ Universitas Veteran Bangun Nusantara Sukoharjo \\ nunun6323@gmail.com
}

\begin{abstract}
The aim of the study are to find Gender discrimination in Novel and acceptability quality of translation from Novel of the girls of the coast. We used methodology of research with descriptive qualitative. The results are $71,43 \%$ acceptability of translation quality with score 3 (high) and social discrimination in subordination $62,5 \%$. The benefit of results are to develop literature of translation quality and analysis discrimination aspect in novel of the girls from the coast. The innovation of novelty are teory and guidance of translation in social and gender discrimination with quality translation.
\end{abstract}

Keywords : Gender Discrimination, Translation Quality, the girls from the coast

\section{Introduction}

Discrimination according to the Big Indonesian Dictionary (KBBI dictionary version online / online / online) is the differentiation of treatment of fellow citizens (based on skin color, class, ethnicity, economy, religion, and so on.

The concept of gender is a trait inherent in men and women which is formed by social and cultural factors, so that several assumptions about the social and cultural roles of men and women are born (Handayani: 11). Muhtar (2002) states that gender is the social gender or the connotation of society to determine social roles based on gender. Hasples and Suriyasanr (2005) stated that gender definition is a social variable to analyze the differences between men and women related to roles, responsibilities and needs as well as opportunities and obstacles.

Muhtar (2002) states that gender is the social gender or the connotation of society to determine social roles based on gender. Hasples and Suriyasanr (2005) stated that gender definition is a social variable to analyze the differences between men and women related to roles, responsibilities and needs as well as opportunities and obstacles. From some of the definitions described above, it can be concluded that gender is the distinction between the sexes of men and women so that certain labels appear. So that gender discrimination can lead to unfair attitudes and behavior towards certain genders. There have been many studies on gender discrimination but 
none have touched on the discussion of gender discrimination associated with translation.

Research conducted by M. Novitasari (2018) entitled Gender Discrimination of Popular Cultural Products (Sara Mills Discourse Analysis on Entrok's novel). This study aims to describe the acts of gender discrimination in the novel entitled "Entrok", and to find out the forms of gender injustice experienced by women at that time.

Research conducted by Uman Rejo (2012) entitled Discrimination of social class and gender in Oka Rusmini's Novel Tarian Bumi. This study aims to determine / explore the social class and gender discrimination in the novel.

Furthermore, research conducted by S. Sutardi (2016) entitled Social Implications of Gender Discrimination (Study on Gender in Bungung Katammung Village, Bantaeng Regency). This study aims to reveal the causes and forms of gender discrimination.

Pramoedya Ananta Toer's novel, entitled Beach girls, is full of phrases that show gender discrimination and social class discrimination, for example: "Child women, when we are married, the bad boys are bad, the good men, the better we are" (14), a further example. : "Here you can't work. Your hands must be smooth like velvet, the main woman must not be rough "(32).

Looking at the examples of expressions contained in the novel Gadis Pantai by Pramoedya Ananta Toer above, this is where the role of the translator is very important, and the task is very heavy because he is required to be able to maintain the results of his translation and still be able to show expressions that show gender discrimination. Now the challenge for translators is whether or not the translator in translating while maintaining the expressions that show gender discrimination.

Thus, based on the background and after seeing examples of expressions contained in the novel Gadis Pantai, the researcher was moved and interested, wanted to conduct research, to find out more about the discriminatory expressions contained in the novel and wanted to know the quality of the translation. In this research, the author gives the title Study of the Quality of Translation of Phrases that Indicate Gender Discrimination in the Novel, Gadis Pantai by Pramoedya Ananta Toer, from Indonesian into English.

By looking at the background to the problems mentioned above, the problems studied in this study are as follows:

1. What is the form of gender discrimination in expressions that show gender discrimination in the novel Gadis Pantai by Pramoedya Ananta Toer?

2. How acceptable is the quality of the translation of the expressions that show gender discrimination in the English translation, The Girl from the Coast from the novel Gadis Pantai?

\section{Purpose}

1. To find out the form of gender discrimination in expressions that show gender discrimination in the novel Gadis Pantai by Pramoedya Ananta Toer. 
2. To determine the acceptability of the translation quality of expressions that show gender discrimination in the English translation, The Girl from the Coast from the novel Gadis Pantai.

\subsection{Targeted Innovations}

Theories and guidelines for translating expressions of gender discrimination in terms of quality of translation.

\section{Literature review}

\subsection{Theoretical study}

This research is an analysis of the quality of the translation of expressions that show social class and gender discrimination contained in the novel Gadis Pantai by Pramoedya Ananta Toer, so that it is hoped that the results of this study can be used as a reference in translating expressions that show social class discrimination and discrimination. gender, so that the translation results are of high quality, that is, they can get high acceptance from readers of the target language, or users of the translated work.

An theories and guidelines for translating expressions of gender discrimination in terms of quality of translation.

\subsection{Translation}

The definition of translation has been put forward by many experts, among others, by New Mark (1988: 5) saying that: "Translation is rendering the meaning of a text into another language in the way that the author intended the text.

Then the next definition put forward by Sperber and Wilson in Bell (1991: 6) says that: "Translation is the replacement of a representation of a text in one language by a representation of an equivalent text in a second language".

If we look at the two definitions above, we can conclude that translation is the transfer of messages from the source language into the target language.

\subsection{Acceptability of Translation Quality and its Assessment}

Larson (1991: 485) says that:

There are three main reasons for testing a translation. The translator wants to be sure his translation is accurate, clear, and natural. These three features are important throughout the translation, so the entire translation must be checked for each one.

From the reasons given by Larson above, we can see that the translation must be tested because the translator wants to make sure that the translation is accurate, clear, fair. These three reasons are the main reasons that the translation work must be tested.

In order to maintain the quality of the translation results, a translator must: 1. have perfect and up-to-date knowledge of the source language; 
2. understand the material to be translated;

3. Know the equivalent terminologies for the translation into the target language;

4. Ability to express and appreciate and feel style, rhythm, nuance and register both source language and target language (Ian Finlay, 19971 in Yusuf, 1994).

There are many translation experts who provide ways of evaluating the quality of the translation work, including Rochayah Machali (2000: 119-120). In his book Guidelines for Translators, he provides signs for translation assessments, as follows:

\begin{tabular}{|c|c|c|}
\hline CATEGORY & SCORE & INDICATOR \\
\hline $\begin{array}{l}\text { Almost perfect } \\
\text { translation }\end{array}$ & $\begin{array}{c}86-90 \\
\text { (A) }\end{array}$ & $\begin{array}{l}\text { The delivery is fair, hardly feels like a } \\
\text { translation; no spelling mistakes; there are } \\
\text { no grammatical errors / irregularities; } \\
\text { there is no misuse of the term. }\end{array}$ \\
\hline Excellent Translation & $\begin{array}{c}76-85 \\
\text { (B) }\end{array}$ & $\begin{array}{l}\text { There is no distortion of meaning; no rigid } \\
\text { literal translation; there are no mistakenly } \\
\text { used terms; there are one or two grammar } \\
\text { / spelling mistakes (for Arabic there are } \\
\text { no spelling mistakes). }\end{array}$ \\
\hline Good Translation & $\begin{array}{c}61-75 \\
(\mathrm{C})\end{array}$ & $\begin{array}{l}\text { There is no distortion of meaning; there is } \\
\text { a rigid literal translation, but relatively no } \\
\text { more than } 15 \% \text { of the entire text, so that it } \\
\text { doesn't feel too much like a translation; } \\
\text { relative grammar and idiom errors make } \\
\text { up no more than } 15 \% \text { of the entire text. } \\
\text { There are one or two uses of the term } \\
\text { which are not standard / general. There } \\
\text { are one or two spelling errors (for Arabic } \\
\text { there are no spelling mistakes). }\end{array}$ \\
\hline Average Translation & $\begin{array}{l}40-60 \\
\text { (D) }\end{array}$ & $\begin{array}{l}\text { Feels like a translation; there are some } \\
\text { rigid literal translations, but no more than } \\
25 \% \text { relative. There are some idiom and / } \\
\text { grammar mistakes, but telative is not } \\
\text { more than } 25 \% \text { of the entire text. There } \\
\text { are one or two uses of the term that are } \\
\text { not standard / uncommon and / or unclear. }\end{array}$ \\
\hline Poor Translation & $\begin{array}{c}20-45 \\
(\mathrm{E})\end{array}$ & $\begin{array}{l}\text { Feels like a translation; too many rigid } \\
\text { literal translations (relatively more than } \\
25 \% \text { of the entire text). There are } \\
\text { distortions of meaning and misuse of } \\
\text { terms in more than } 25 \% \text { of the entire text. }\end{array}$ \\
\hline
\end{tabular}

Sumber : Machali (2000) 
There are many more translation experts who provide a way to assess the quality of the translation, but researchers tend to choose the translation assessment strategy proposed by Nababan and friends (2012) because the translation assessment strategy provided by them is that the measuring tool is clearer, namely the assessment parameter number $3,2,1$.

Translation acceptability parameters. Acceptability relates to a person's preference for word choice, sentence or paragraph construction (New Mark, 1988: 191)

The following is the researcher conveying the parameters given by Nababan (2012: 51)

dan kawan-kawan berkenaan dengan keberterimaan kualitas terjemahan:

Table Assesment Instrument of Acceptable Translation

\begin{tabular}{|l|l|l|}
\hline $\begin{array}{l}\text { Translation } \\
\text { Category }\end{array}$ & Score & Qualitative Parameter \\
\hline Acceptable & 3 & $\begin{array}{l}\text { Translation feels natural; technical terms used are commonly } \\
\text { used and familiar to readers; The phrases, clauses and } \\
\text { sentences used are in accordance with the rules of the } \\
\text { Indonesian language. }\end{array}$ \\
\hline $\begin{array}{l}\text { Lack of } \\
\text { Acceptability }\end{array}$ & 2 & $\begin{array}{l}\text { In general, the translation feels natural; however, there is little } \\
\text { use of technical terms or there is some slight grammatical } \\
\text { error. }\end{array}$ \\
\hline Unacceptable & 1 & $\begin{array}{l}\text { Translation is unnatural or not feels translation work; technical } \\
\text { terms that have been used are not commonly used and are not } \\
\text { familiar to the reader; The phrases, clauses and sentences used } \\
\text { are not in accordance with Indonesian language rules. }\end{array}$ \\
\hline
\end{tabular}

\subsection{Gender Discrimination}

Fulthoni (internet) discrimination is unfair and unbalanced treatment carried out to distinguish individuals, or groups, based on something, usually categorical, or specific attributes, such as based on race, ethnicity, ethnicity, religion, or class membership. social. Other experts, Sears, Freedman, and Peplau, said that discrimination is a behavior that shows rejection of an individual or group solely because of one's membership in the group.

Looking at the definitions of some of the experts mentioned above, it can be concluded that discrimination is differentiated because of position, rank, degree, education, socio-economic status and also because of their respective roles in life. The existence of gender differences / discrimination creates injustice.

\subsection{GENDER DIFFERENCE / DISCRIMINATION GIVES IN JUSTICE}


Handayani Tri Sakti and Sugiarti (2008: 14-19) convey that gender injustice is manifested in the form of injustice, for example:

1. Marginalization of women.

The marginalization of women here can be manifested, for example in agriculture, there was a green revolution that focused on male farmers resulting in many women displaced and becoming poor. There are other examples, namely the existence of special jobs for women, such as child teachers, factory workers which result in low wages.

2. Subordination of women's work.

Subordination is the assumption that women are not important in making decisions. This is due to the assumption that women are irrational or emotional, so that women cannot appear to lead and result in the emergence of attitudes that place women in an insignificant position.

3. Stereotypes,

Stereotype is a labeling of a certain group, and usually this labeling always results in injustice, so it is called negative labeling.

4.Violence against women.

Violence is an assault against a person's physical and psychological mental integrity. Violence against humans has many sources, but there is one type of violence that is based on gender assumptions. This violence is referred to as "gender-related violence, which is basically caused by power.

5. Workload.

Because there is an assumption that women are nurturing, diligent and will not be the head of the household, consequently all domestic work is the responsibility of women. Therefore women receive a double burden, apart from having to work domestically, they still have to work to help earn a living.

\section{Research Methodology}

\subsection{Research Design}

This research is a qualitative descriptive research, because this research is able to capture various qualitative information with careful descriptions. Sutopo (2002: 35) argues that qualitative research focuses on data in the form of words, sentences or images which have more meaning than just numbers or frequencies that are holistic, and by describing them in the form of words and language. The research strategy used in this research is a fixed case study, because the problems and focus studied are predetermined as contained in the problem formulation, and the data in this study are in the form of gender discrimination expressions contained in the novel Pramoedya Ananta Toer. entitled Beach Girls and the quality of translation in English, in the category of translation acceptability.

\subsection{Research Location}

The research location is a limitation that the researcher determines the limit of his research focus. Riyadi (2014: 47) says that the research location is a "focus- 
determined boundary", which means that the boundaries are determined by the focus or research object ". The focus of the research carried out is in the media of the novel, entitled "Pantai Gadis", to find expressions that show gender discrimination and their translation in English entitled "The girl from the coast", to determine the quality of the translation, which is categorized as acceptable.

\subsection{Data and Data Sources}

There are two categories of data in this study, namely primary data in the form of linguistic data and translation data and secondary data. The primary data is in the form of expressions containing gender discrimination in the novel entitled "Pantai Gadis", and the translation data is the translation result in English entitled "The girl from the Coast". namely about the quality of the translation which is in the acceptable category. The second data is secondary data, namely data that comes from outside the text consisting of informants or raters.

The source of qualitative research data by Sutopo (2002: 50-54) states that it can be various, namely humans, events or activities, places or locations, objects, various pictures, and recordings, as well as documents and archives. So that the data sources in this study are based on the explanation above, namely: data in the form of expressions which constitute gender discrimination from a data source in the form of a novel entitled "Pantai Gadis" and data on the quality of translation which is categorized as translation acceptability is obtained from informant / rater data sources. .

\subsection{Sampling Technique}

Sampling Technique uses two kinds of analysis such as document and Focus group discussion (FGD).

\subsubsection{Document Analysis}

Yin in Sutopo (2006: 81) states that document analysis is a data collection technique based on documents. The documents analyzed are research findings that show expressions of gender discrimination.

This method is done by studying the contents of the source language text and the target language carefully, to obtain data, the researcher analyzes the novel Gadis Pantai to identify expressions which constitute gender discrimination.

\subsubsection{Focus Group Discussion}

Focus Group Discussio (FGD) or focus group discussions aim to equalize perceptions of the quality of translation. FGD is one of the most efficient data collection techniques because if there are things that are still in doubt, they can be discussed and resolved during the FGD. Those involved in the FGD were translating experts and researchers. They were invited to discuss determining the value of the quality of the translation of expressions that show gender discrimination. One of the instruments in the FGD is a questionnaire. Sutopo (2002) states that the questionnaire is a list of questions for data collection in research. The questionnaire used in the 
FGD was to obtain data on the quality of translations in the translation acceptability category. This questionnaire will later be given to informants / rater and discussed in the FGD. The informants were asked to fill in the quality scale rating table with numbers 3,2, and 1. The scale rating refers to Nababan, et al. (2012: 51).

\subsection{Data Validity Check Techniques}

In this study, researchers conducted triangulation to increase the validity of the data. Triangulation technique is a data collection technique or a technique to check the credibility of data by combining various data collection techniques and existing data sources (Sugiyono: 2012: 241). According to Patton in Sutopo (1996: 70) there are four types of triangulation, namely data / source triangulation, researcher triangulation, methodological triangulation, and theory triangulation.

In this study, researchers performed data / source triangulation techniques and triangulation methods:

(1) Data / source triangulation

Data / source triangulation is the use of multiple data sources in a study. The triangulation of data sources in this study is in the form of documents, namely the Source Language novel entitled Pantai Gadis and the translation novel in English. The second source of data is from the informant / rater to get the right answer for each assessment of the translation result, to determine the quality of the translation seen from the acceptance of the translation.

(2) Triangulation method.

Triangulation method is a triangulation technique related to techniques of obtaining or collecting data (Riyadi, 2014: 48). In this study, researchers used document analysis methods and FGD methods. Researchers read the novel Gadis Pantai, then analyzed it, the second method, namely FGD, which is analyzed in the FGD is the translation data, namely about the quality of the translation, which is related to the acceptability of the translation.

\subsection{Data Analysis Technique}

Data Analysis Technique uses technique from Spradley (1980, in Santosa,2014:66) such as domain, taxonomic, componensial, culture analysis.

\subsubsection{Domain Analysis.}

In this analysis, namely to distinguish which is included as data and which is not data. The next step, after knowing which one is included in the data, is then placed into the domain according to the context. In this study, sorting out which one includes gender discrimination and not. If the expression indicates gender discrimination, the expression is categorized into the data.

Note that domain analysis also determines the origin of the data. The data in this study, the data comes from conversations in the novel. It means that the domain is novel. So not in real life everyday.

The domain analysis in this study is as follows: 


\begin{tabular}{|c|c|c|c|c|}
\hline No. & Contexts & Source Language & Target Language & $\begin{array}{l}\text { Data / Not } \\
\text { Data }\end{array}$ \\
\hline 1 & $\begin{array}{l}\text { The Beach Girl's } \\
\text { mother tries to } \\
\text { comfort the Beach } \\
\text { Girl who is sad } \\
\text { because she has to } \\
\text { marry a man who is } \\
\text { not her choice }\end{array}$ & $\begin{array}{l}\text { Girls, children, } \\
\text { when we are } \\
\text { married, our bad } \\
\text { boys are bad, our } \\
\text { good boys are } \\
\text { good. What's not } \\
\text { so nice to him? (p. } \\
\text { 14) }\end{array}$ & $\begin{array}{l}\text { When a woman } \\
\text { marries, child, she } \\
\text { becomes bad if her } \\
\text { man is bad, and good } \\
\text { if he is good. What } \\
\text { fault can one find in } \\
\text { him? (hal. 3) }\end{array}$ & Data \\
\hline 2 & $\begin{array}{l}\text { By riding a cart, } \\
\text { her parents } \\
\text { escorted her } \\
\text { parents to her } \\
\text { future husband's } \\
\text { house }\end{array}$ & $\begin{array}{l}\text { "Come down, } \\
\text { son", but his eyes } \\
\text { are scattered } \\
\text { everywhere, } \\
\text { finally stopping at } \\
\text { the gate he was } \\
\text { about to pass (p. } \\
\text { 15) }\end{array}$ & $\begin{array}{l}\text { "Get down, nak", he } \\
\text { said, looking all } \\
\text { around. Finally, his } \\
\text { gaze came to rest on a } \\
\text { gateway. (hal 4) }\end{array}$ & Not Data \\
\hline
\end{tabular}

\subsubsection{Taxonomic Analysis}

Santosa (2017: 78) says that the purpose of taxonomic analysis is to reduce large data into groups based on their natural categories. In this study, taxonomic analysis was carried out by classifying all collected data into categories based on data characteristics. After the data on expressions showing gender discrimination are found, then they are categorized based on

the forms of discrimination are marginalization, subordination, stereotypes, violence and workload. With regard to the translation quality, the characteristics of the data are broken down into several sub-categories.

\subsubsection{Componential Analysis}

Santosa (2017: 84) says that Comparative Analysis is carried out by connecting between components or aspects (in this case between domains and categories) that have been carried out in domain and taxonomic analysis. The goal is to find patterns of relationships between components. In this study, the relationship between forms of gender discrimination and the quality of translation.

\subsubsection{Analysis of Cultural Themes}

Santosa (2017: 93) says that analysis of cultural themes is an analysis of looking for theories based on research results. Analysis of cultural themes in this study will be based on the interpretation of data that can be seen from the comparative analysis, forms of gender discrimination and an assessment of the quality of the translation.

\section{Finding and Discussion}

\subsection{Acceptance of translation}


The study found the acceptance level of points 3 and point 2 based on the acceptance criteria for translation according to Nababan (2012). The study resulted in the findings of 56 acceptance data where there was no data with acceptance level 1.

\section{Acceptance in Point 3}

Example 1 (Point 3) :

Bsu : “Tak patutlah orang setua ini berjingkrak seperti bocah.”(Hal 177)

Bsa : "What's an old man supposed to do? Jump up and down like a little boy?" (Page 179)

Example 2 (point 3)

Bsu : Di Sini kau tidak boleh kerja. Tanganmu harus halus seperti beludru, wanita utama tidak boleh kasar (Hal 32)

Bsa : "You mustn't work,"Your Hands must be as soft as velvet. There must be nothing coarse about the principal consort of this house. "(Page 20)

\section{Acceptance in Point 2}

Example 1 (Point 2):

Bsu : "Bukan galibnya lagi anak terhormat dipanggil pada namanya" (hal 175)

Bsa : "That wouldn't be right, not for someone of your standing." (Page 176)

Example 2 (point 2)

Bsu : Orang Mulia, pikirnya tak perlu terkelantang di terik matahari. (hal 33)

Bsa : The complexion of a person who had never had to work in the ot day's sun. (Page 27)

Tabel 4.1 Results of Acceptance of Translation

\begin{tabular}{|l|l|l|l|l|}
\hline No & Scale of Acceptance & Criteria (Nababan, 2012) & Total & $\%$ \\
\hline 1. & Point 3 (Acceptance) & $\begin{array}{l}\text { Translation feels natural, the } \\
\text { technical terms used are commonly } \\
\text { used and familiar to readers, the } \\
\text { phrases, clauses and sentences used } \\
\text { are in accordance with Indonesian } \\
\text { language rules. }\end{array}$ & 71,43 \\
\hline 2 & Point 2 (Poor) & $\begin{array}{l}\text { In general, the translation feels } \\
\text { natural; however, there is little use of } \\
\text { technical terms or there is some slight }\end{array}$ & 16 & 28,57 \\
\hline
\end{tabular}




\begin{tabular}{|l|l|l|l|l|}
\hline No & Scale of Acceptance & Criteria (Nababan, 2012) & Total & $\%$ \\
\hline 3 & Point 1 (None) & $\begin{array}{l}\text { grammatical error. } \\
\text { Translation is unnatural or not feels } \\
\text { translation work; technical terms that } \\
\text { have been used are not commonly } \\
\text { used and are not familiar to the } \\
\text { reader; The phrases, clauses and } \\
\text { sentences used are not in accordance } \\
\text { with Indonesian language rules. }\end{array}$ & 0 \\
\hline & \multicolumn{1}{|l|}{ Total } & 56 & 100 \\
\hline
\end{tabular}

Source: Data processed (2020)

Based on Table 4.1 the results show that $71.43 \%$ of the acceptance of the quality of the translation has point 3 , the results of $28.57 \%$ have point 2 and no results are found for the quality of acceptance that has point 1 . The total sample of acceptance quality findings used is 56. It was concluded that the overall level of acceptance of the translation of the coastal girl novel was high.

\subsection{Results of social Discrimination}

Table 4.2 Results of social Discrimination Model

\begin{tabular}{|l|l|l|l|}
\hline No & Discrimination Model & Total & $\%$ \\
\hline 1 & Marginalization & 0 & 0 \\
\hline 2 & Subordination & 35 & 62,5 \\
\hline 3 & The Streotif view & 11 & 19,65 \\
\hline 4 & Violence & 10 & 17,85 \\
\hline 5 & Workload & 0 & 0 \\
\hline & Total & 56 & 100 \\
\hline
\end{tabular}

Source: processed data (2020)

Table 4.2 shows that the form of discrimination is $62.5 \%$ subordinated, $19.65 \%$ stereotypical, $17.85 \%$ violence, and there is no form of discrimination or marginalization of workload. The number of sample findings used was 56 data.

The Results of Discrimination Model

1) Subordination

Example :

Bsu : Perempunan Nak, kalau sudah kawin, jeleknya laki jeleknya kita, baiknya laki, baiknya kita.

Bsa : When a woman marries bad, life is going to be all the worse for her, "she stressed, "But when she marries good, then it's good for her, too. (page 7)

2) Stereotypes

Example : 
Bsu : "Jangan pikirkan orang lelaki mas Nganten, biarpun Bapak Sendiri. Lelaki tahu bawa diri, biarpun di neraka. (hal 65)

Bsa : "Don't about men, "the older woman advised," ever your own father. Men can always take care of themselves, even in hell no doubt."(page 59)

3) Violence

Example :

Bsu : Tak boleh punya sahabat, Cuma boleh menunggu perintah, Cuma boleh memerintahkan.

Bsa : "She wasn't allowed to have friends. All she could do was give orders or wait for them to be given to her".

\subsection{Discussion}

The translation work of the novel girl Pantai by Pramoedya Ananta Toer has a high level of acceptance of the translation with a percentage of $71.43 \%$. Pramoedya Ananta Toer's novel coastal girls also shows that subordinated social class discrimination is $62.5 \%$. These results indicate that the coastal girl novel is more easily accepted and understood by foreign readers, especially English. The beach girl novel explores the novel so well with the adaptation of the beach girl storyline that social discrimination is inherent in the novel.

\section{Conclusions and suggestions}

\section{Conclusion}

The research aims to examine the forms of gender discrimination by Pramoedya Ananta Toer's translation of the beach girl and the quality of the acceptable translation. The results show that:

1. The acceptance rate for Gadis Pantai novel is $71.43 \%$ with a high score (3 points).

2. The level of social discrimination in the subordination type is $62.5 \%$.

\section{Suggestion}

For further researchers, they can develop literature related to the accuracy of Pramoedya Ananta Toer's novel from readers of different backgrounds so that they are more biased to adapt to culture.

\section{References}

Larson, M.L. (1998). Meaning-Based Translation: A Guide To Cross-Language Equivalence. USA: University Press of America. 
Machali, R. (2000). Pedoman Bagi Penerjemah. Jakarta: P.T.Grasindo Gramedia Widiasarana.

Nababan, M., Nuraeni, A., dan Sumardiono. (2012). Model Penilaian Kualitas Terjemahan. Jurnal Kajian Linguistik dan Sastra, 24, 1, 39-57.

Newmark, P. (1988). A Textbook of Translation. Hertfordshire: Prentice Hall International Ltd.

Riyadi, S. (2014). Draf Buku Metode Penelitian Kualitatif Kebahasaan. Surakarta: Universitas Sebelas Maret.

Spradley, J.P. (1980). Metode Etnografi. (Diterjemahkan oleh Misbah Yulfa Elisabeth). Yogyakarta: PT. Tiara Wacana Yogya.

Sutopo, H.B. (2002). Metodologi Penelitian Kualitatif. Surakarta: Sebelas Maret University Press.

Yang, L. (2014). A Gender Perspective of Translation: Taking Three Chinese Versions of The Purple Color as an Example. Journal of Language Teaching and Research, 5, 2, 371-375. 